\title{
Comparable membrane permeability can be achieved in granular and flocculent anaerobic membrane bioreactor for sewage treatment through better sludge blanket control
}

\author{
K.M. Wang ${ }^{a}$, A. Soares ${ }^{a}$, B. Jefferson ${ }^{a}$, E. J. McAdam ${ }^{a^{*}}$ \\ ${ }^{a}$ Cranfield Water Science Institute, Vincent Building, Cranfield University, Bedfordshire, MK43 OAL, UK \\ *Corresponding author: e.mcadam@cranfield.ac.uk
}

\section{Highlights}

- UASB configured AnMBRs are viable for municipal wastewater treatment

- At $20^{\circ} \mathrm{C}$, membrane permeability of granular and flocculent AnMBR is comparable

- At $10^{\circ} \mathrm{C}$, flocculent UASB solids breakthrough increases membrane fouling

- Pseudo dead-end gas sparging achieves energy neutral sewage treatment for both MBR

- Solids management strategy ensures flocculent AnMBR comparable to granular

\section{Abstract}

In this study, granular and flocculent sludge are compared as seeding options for both upflow anaerobic sludge blanket (UASB) reactor and UASB configured anaerobic MBR (AnMBR), to establish the impact of each biomass on delivering sustained membrane permeability for settled municipal wastewater treatment. When operated in UASB mode at around $10^{\circ} \mathrm{C}$, similar poor UASB treatment performance were observed for both inoculum sludge types, which can be overcome by membrane integration with solids-free permeate and consistently low in $\mathrm{COD}_{\mathrm{t}}\left(34-39 \mathrm{mg} \mathrm{L}^{-1}\right)$ and $\mathrm{BOD}_{5}\left(10-13 \mathrm{mg} \mathrm{L}^{-1}\right)$, sufficient to conform to discharge standards. When operated at an average sewage temperature of $22^{\circ} \mathrm{C}$, membrane permeabilities in granular (G-AnMBR) and flocculent (F-AnMBR) systems were comparable. However, when operated at a low average temperature of $10^{\circ} \mathrm{C}$, significant fouling was observed in F-AnMBR when operated at a flux of $7.5 \mathrm{~L} \mathrm{~m}^{-2} \mathrm{~h}^{-1}$. The permeability decline was ascribed to a decreased particle settling velocity which induced smaller particles washout into the downstream membrane tank, and subsequently increased the colloidal concentration due to the floc particles erosion induced by gas sparging. This was confirmed by halving UASB upflow velocity in the F-AnMBR, which reduced pCOD and colloidal load by $31-36 \%$ onto the membrane, permitting comparable permeability to G-AnMBR. The UASB configuration promoted a low solids loading onto the membrane, which allowed a pseudo dead-end gas sparging strategy to be used in order to reduce specific energy demand. Analysis of the pseudo 
dead-end filtration cycle demonstrated that the primary resistance $(85-88 \%)$ was associated to the development of a more concentrated organic cake. Importantly, this study provides the first comparison of G-AnMBR and F-AnMBR both in UASB configuration and demonstrates that sustained low energy membrane operation with $0.122 \mathrm{kWh} \mathrm{m}^{-3}$ can be achieved in both systems provided solids flux onto the membrane is managed through controlling solids retention in the UASB, and specifying cycle length to avoid the onset of a critical solids deposition.

Keywords: $U A S B, M B R$, resilience, energy, inocula

\section{Introduction}

Anaerobic processes are an attractive alternative to aerobic technologies for municipal wastewater treatment at ambient temperature, as they use less energy, produce less sludge and can increase the energy recovered from wastewater through biogas production [1]. The key challenge for anaerobic processes is to prevent biomass washout due to the slow growth rate of anaerobic bacteria. Such effects are exacerbated in municipal wastewater treatment as low sewage temperatures and limited substrate availability also constrain growth. Upflow anaerobic sludge blanket (UASB) reactors are high-rate anaerobic technology widely used for municipal wastewater treatment, where the upflow velocity $\left(V_{u p}\right)$ introduces a hydraulic selection pressure that extends the solids retention time (SRT) and increases biomass concentration [2]. Several authors have investigated integrating UASB reactors into anaerobic membrane bioreactor (AnMBR) technology, where the membrane guarantees independent control of SRT from hydraulic retention time (HRT) thereby avoiding washout [3] and produces solids-free permeate with low chemical oxygen demand (COD) [1]. The few studies that compared AnMBR configurations, have shown that UASB configured AnMBR achieved higher permeabilities due to the lower solids concentration in the membrane tank which seemingly limits cake layer formation [4-6]. Martin-Garcia et al. [1] illustrated that a significant reduction in gas sparging frequency was achievable because of the low solids concentration in a granular UASB configured AnMBR, and adopted a pseudo dead-end strategy comprising gas-sparging $1 \mathrm{~min}$ every $10 \mathrm{~min}$ during a period of relaxation. This provided considerable reduction in 
membrane energy demand and has since been demonstrated as sufficient to enable energy neutral sewage treatment, which remains a core objective of this technology [7]. However, to sustain membrane permeability in UASB configured AnMBR in the long-term, sludge blanket stability in the UASB needs to be maintained as breakthrough of the particulate organic fraction will inevitably increase fouling.

Starting up AnMBR without previously inoculating the reactor, introduces a significant lag time before steady-state is reached (up to 6 months) and is not feasible for industrial scale applications [2]. Therefore inoculation is undertaken using either granular or flocculent biomass $[2,8]$. Granular biomass has been shown to possess superior settling characteristics $[9,10]$ and higher specific methanogenic activity [11], subsequently providing improved treatment performance versus flocculent UASB reactors. However, much of this knowledge is based on treatment of soluble industrial wastewater [12] rather than municipal wastewater [13], the latter being inherently more complex due to the broad particle size distribution of the influent organic fraction [4]. Integration of membrane technology partially offsets the perceived limitation of flocculent sludge through providing definitive solids separation, but poor sludge retention in the UASB could then influence membrane permeability through increasing solids loading onto the membrane. Whilst granular sludge appears favourable, anaerobic granules do not evidently grow in sewage, and as sources are presently limited, costs of 500 to 1000 USD per ton wet weight have been reported $[8,9,11]$. During operation, granule disintegration has also been noted which could influence membrane permeability and therefore presents a risk to overall process resilience [14].

To date, very few studies have investigated granular inoculum in AnMBR [1,4,15]. Martin et al. [1,4] compared a granular UASB (G-UASB) configured AnMBR to a flocculent CSTR configured AnMBR and identified the G-UASB configured AnMBR to have lower fouling propensity. However, due to different reactor configurations applied, the direct impact of granular and flocculent inoculum biomass on membrane fouling both in UASB configured AnMBR is still not fully understood. It is crucial to determine the impact and value that each biomass may offer in delivering sustained membrane permeability and ultimately promotes a significant advancement toward low membrane fouling and energy neutral sewage treatment 
with AnMBR. The aim of this study is therefore to establish the impact of inoculum selection on membrane permeability in UASB configured AnMBRs by comparing granular and flocculent UASB reactors performance and UASB configured AnMBR membrane operation. Specific objectives are to: (i) evaluate the transition from UASB to UASB configured AnMBR to determine the impact of membrane integration on separation and bulk sludge characteristics and permeate quality; (ii) to investigate how inoculum selection influences the bulk sludge matrix and membrane fouling propensity in order to ascertain whether the cheaper and easily attainable flocculent biomass can be utilised as an alternative option for potentially costly granular biomass with limited supply in AnMBR; and (iii) to ascertain whether either sludge can sustain membrane permeability using a pseudo dead-end gas sparging strategy to promote low energy membrane operation and therefore approaching to energy neutral sewage treatment.

\section{Method and materials}

\subsection{UASB and UASB configured AnMBR pilot plants}

Two cylindrical UASB reactors ( $0.2 \mathrm{~m}$ diameter $\times 1.8 \mathrm{~m}$ height) were operated in parallel (Model products, Wootton, UK) with a solid/liquid/gas separator located at the top of the column to form a total reactor height of $2.0 \mathrm{~m}$ and total volume of $70 \mathrm{~L}$ (Figure 1). The G-UASB was initially inoculated with $15 \mathrm{~L}$ granular sludge $\left(40 \mathrm{~g} \mathrm{VS}^{-1}\right)$ from a mesophilic UASB used for pulp and paper industry. The flocculent UASB (F-UASB) was inoculated with $15 \mathrm{~L}$ of digested sludge $\left(30 \mathrm{gVS} \mathrm{L}^{-1}\right)$ from a municipal anaerobic digester treating primary and secondary sewage sludge. The sewage sludge comprised 3.6\% total solids (78\% volatile solids). Settled wastewater from Cranfield University's sewage treatment works was fed into the bottom of the two UASB reactors with peristaltic pumps (520U, Watson Marlow, Falmouth, UK). Both the G-UASB and F-UASB were acclimatised at a hydraulic retention time (HRT) of $8 \mathrm{~h}$ for 360 days prior to starting experimentation. Internal recirculation was conducted with peristaltic pumps (620S, Watson Marlow, Falmouth, UK) to maintain the $V_{\text {up }}$ at $0.8-0.9 \mathrm{~m} \mathrm{~h}^{-1}$, which expanded the granular sludge bed height by $30 \%$ of the total column height and permitted stratification of the light sludge fraction (comprising dispersed growth flocs from the influent) above the granular sludge bed $[2,11]$. No stratification was perceived to have occurred in the F-UASB. 
Following conversion of the UASB reactor to an AnMBR, effluent from G-UASB and FUASB overflowed into a $30 \mathrm{~L}$ cylindrical membrane tank (Figure 1). Retentate from the membrane tank was recycled back to the UASB reactor (620S, Watson Marlow, Falmouth, UK). The membrane module (ZW-10) (GE Water \& Process Technologies, Oakville, Canada) comprised four elements each of which consisted of 76 polyvinylidene fluoride (PVDF) hollow fibres $(0.52 \mathrm{~m}$ in length and $1.9 \mathrm{~mm}$ outer diameter) with a nominal pore size of $0.04 \mu \mathrm{m}$, providing total surface area of $0.93 \mathrm{~m}^{2}$. Permeate was withdrawn by a peristaltic pump (520U, Watson Marlow, Falmouth, UK). Transmembrane pressure (TMP) was monitored by a pressure transducer (-1-1bar, Gems sensor, Basingstoke, UK) in the permeate line. Nitrogen-enriched air was produced for gas sparging by a nitrogen generator (NG6, Noblegen gas generator, Dunston, UK). In the standard gas sparging condition, intermittent filtration (10min on/1min off) with cyclic gas sparging (10s on/10s off) was deployed [1]. During the pseudo dead-end (DE) gas sparging strategy, filtration was conducted without gas sparging followed by membrane relaxation coupled with gas sparging (Intermittent filtration, 10min on/1min off; intermittent gas sparging, $1 \mathrm{~min}$ on/10min off). The introduction of gas sparging between filtration cycles was controlled using a solenoid valve (Type 6014, Burkert, Ingelfingen, Germany) connected to a time relay (PL2R1, Crouzet, Valence, France). Specific gas demand per unit membrane area $\left(S_{G} D_{m}\right)$ was set at $1.1 \mathrm{~m}^{3} \mathrm{~m}^{-2} \mathrm{~h}^{-1}$ and controlled by a needle valve (0$30 \mathrm{~L} \mathrm{~min}^{-1}$, Key Instruments, Langhorne, US). In order to directly compare the transition from UASB to UASB configured AnMBR, tests were conducted in the same season with a temperature of $10-13^{\circ} \mathrm{C}$. The HRT was fixed to $8 \mathrm{~h}$ in the UASB which resulted in an initial permeate flux of $12 \mathrm{~L} \mathrm{~m}^{-2} \mathrm{~h}^{-1}$ (normalised to $20^{\circ} \mathrm{C}$ ) [16]:

$$
J=J_{20} \cdot 1.025^{(T-20)}
$$

Subsequent evaluation was undertaken in the summer period, where sewage temperature ranged $21-23^{\circ} \mathrm{C}$.

Cake fractionation was evaluated through resistance in series determination in which the intrinsic resistance of the membrane $\left(R_{m}\right)$ was first determined by clean water permeability test [17]:

$$
\mathrm{R}=\frac{\mathrm{TMP}}{\mu \cdot J}
$$


Following $200 \mathrm{~h}$ of operation (equivalent to a total filtered volume of $1500 \mathrm{~L}$ ), total resistance was determined $\left(R_{\text {total }}\right)$ and the following protocol used for cleaning: $(1)$ rinse with $45 \mathrm{~L}$ clean water; (2) backwash with $45 \mathrm{~L}$ clean water at $22.5 \mathrm{~L} \mathrm{~m}^{-2} \mathrm{~h}^{-1}$ (300\% of permeate); and (3) chemical desorption with sodium hydroxide $(\mathrm{pH}=11-12)$ for $24 \mathrm{~h}$. After each stage, clean water permeability tests were conducted to obtain hydraulic resistance after rinsing ( $\left.R_{\text {rinsed }}\right)$ and backwash $\left(R_{b w}\right)$. The hydraulic resistances of the cake were then classified as: total fouling layer resistance $\left(\mathrm{R}_{\mathrm{TF}}\right)$, and the hydraulic resistance of the upper, intermediate and lower fraction ( $\left.R_{U F}, R_{I F}, R_{L F}\right)$ :

$$
\begin{aligned}
& \mathrm{R}_{\mathrm{TF}}=\mathrm{R}_{\text {total }}-\mathrm{R}_{\mathrm{m}} \\
& \mathrm{R}_{\mathrm{UF}}=\mathrm{R}_{\text {total }}-\mathrm{R}_{\text {rinsed }} \\
& \mathrm{R}_{\mathrm{IF}}=\mathrm{R}_{\text {rinsed }}-\mathrm{R}_{\mathrm{bw}} \\
& \mathrm{R}_{\mathrm{LF}}=\mathrm{R}_{\mathrm{bw}}-\mathrm{R}_{\mathrm{m}}
\end{aligned}
$$

where $J$ is the permeate flux $\left(\mathrm{L} \mathrm{m}^{-2} \mathrm{~h}^{-1}\right)$ and $\mu$ is the permeate viscosity $\left(\mathrm{Pa} \mathrm{s}^{-1}\right)$. Filtration cycle analysis was completed following pseudo dead-end filtration, with three characteristics determined [17]. Transmembrane pressure $\left(\mathrm{TMP}_{\mathrm{i}}\right)$ at the commencement of each filtration cycle is related to hydraulic resistance by $R_{m}$ and the internal residual fouling resistance $\left(R_{\mathrm{if}}\right)$ :

$$
T M P_{i}=J \cdot \mu \cdot\left(R_{m}+R_{i f}\right)
$$

Within the filtration cycle, fouling through cake formation is generally characterised by a linear increase in TMP. The slope of the straight line can be defined as cake fouling rate $\left(r_{f}\right)$ :

$$
T M P=T M P_{i}+r_{f} \cdot t
$$

The reduction in TMP following cake layer formation $\left(\Delta T M P_{c}\right)$ can be considered a surrogate of the suspension characteristics [18]:

$$
\Delta T M P_{c}=T M P-T M P_{i}=\mu \alpha \varpi J^{2} t
$$

where $\alpha$ is specific cake resistance $\left(\mathrm{m} \mathrm{kg}^{-1}\right), \omega$ is the solids concentration in the cake per unit filtrate volume (assuming similar to MLSS concentration in the bulk sludge, $\mathrm{kg} \mathrm{m}^{-3}$ ).

\subsection{Analytical methods}

Biological oxygen demand $\left(\mathrm{BOD}_{5}\right)$ and mixed liquor suspended solids (MLSS) were measured according to Standard Methods [19]. Total and soluble COD (GF/C grade filter, Whatman, GE Healthcare Life Sciences, Little Chalfont, UK) was analysed with Merck test kit (Merck KGaA, 
Darmstadt, Germany). Particle size and zeta potential were measured with Mastersizer 3000 and Zetasizer Nano ZS respectively (Malvern Instruments Ltd, Malvern, UK). Protein concentration was measured using the modified Lowry method ( $\left.U V_{750 \mathrm{~nm}}\right)$, while carbohydrate concentration was measured using the Dubios phenol sulphuric acid method ( $U V_{490 \mathrm{~nm}}$ ) (Acros Organics, UK).

Molecular weight fractionation was conducted at room temperature $\left(20^{\circ} \mathrm{C}\right)$ to determine the colloidal distribution (Amicon 8400 series stirred cell, Millipore HQ, Billerica, USA). Samples were subject to 2 bar pressure introduced through nitrogen-enriched air (BOC Ltd, Guildford, UK) and a filtrate/retentate ratio of 0.4 used to avoid concentration polarisation. A bench scale cross-flow membrane cell (CF-042, Sterlitech Corporation, Kent, USA) with flat sheet membrane (pore size $=0.08 \mu \mathrm{m}$ ) was used as a diagnostic tool to determine the critical flux $\left(J_{c}\right)$ of the suspension before and after membrane integration; all experiments were conducted under standard conditions $\left(20^{\circ} \mathrm{C}\right)$. Critical flux tests were determined with the flux step method [20] in which successive filtration with flux steps of $2 \mathrm{~L} \mathrm{~m}^{-2} \mathrm{~h}^{-1}$ were maintained for 15 mins and average TMP was monitored. All analyses were conducted in triplicate. Statistical analysis was completed to first evaluate normality through Shapiro-Wilk tests. Where normal distributions were observed, ANOVA tests were applied otherwise nonparametric Mann-Whitney $U$ tests for independent data were used. Analysis was based on $95 \%$ confidence limit $(p<0.05)$.

\section{Results}

\subsection{Transition in bulk sludge characteristics following introduction of the membrane} When operated in UASB mode at around $10^{\circ} \mathrm{C}$ (Figure 1a), similar low TSS, $\mathrm{COD}_{\mathrm{t}}$ and $\mathrm{BOD}_{5}$ removal were observed for both inoculum sludge types, recording 39-42, 36-41 and 19-26\% respectively (Table 1). Following conversion of the UASB to AnMBR through introduction of downstream ultrafiltration (Figure 1b), permeate produced from both AnMBR was solids free and consistently low in $\mathrm{COD}_{\mathrm{t}}\left(34-39 \mathrm{mg} \mathrm{L}^{-1}\right)$ and $\mathrm{BOD}_{5}\left(10-13 \mathrm{mg} \mathrm{L}^{-1}\right)$ respectively, sufficient to conform to discharge standards (Table 1) [1]. After the membrane addition, an increase in bulk sludge SMP concentration by about 2-4 times and particulate COD fraction by 6-9 times were observed for both sludge types and was coincident with a reduction in median particle size 
$\left(d_{50}\right)$; the SMP and PCOD concentrations were significantly higher in the F-AnMBR $(p<0.05)$ (Table 2). Fractionation of the SMP evidenced a relative increase in the higher molecular weight fraction especially for molecular weight (MW) between $500 \mathrm{kDa}$ and $1.2 \mu \mathrm{m}$, whereas the actual SMP concentration in the $10 \mathrm{kDa}$ fraction remained the same, and was similar for both AnMBRs (Table 3).

External membrane cell was used as a diagnostic tool to characterise the critical flux of the suspensions before and after membrane integration. Critical flux $\left(J_{c}\right)$ of the suspensions of G-UASB and F-UASB effluent was similar at 10-12 $\mathrm{L} \mathrm{m}^{-2} \mathrm{~h}^{-1}$. After membrane integration, the critical flux of both suspensions taken from G-AnMBR and F-AnMBR membrane tank reduced to 6-8 $\mathrm{L} \mathrm{m}^{-2} \mathrm{~h}^{-1}$. Whilst similar $J_{c}$ were identified, permeability for the F-AnMBR suspension was considerably below G-AnMBR. To illustrate, at a flux step of $10 \mathrm{~L} \mathrm{~m}^{-2} \mathrm{~h}^{-1}$, permeabilities were 67 and $177 \mathrm{~L} \mathrm{~m}^{-2} \mathrm{~h}^{-1}$ bar $^{-1}$ for the F-AnMBR and G-AnMBR membrane tank suspensions respectively (Figure 2 ).

\subsection{Membrane operation comparison between G-AnMBR and F-AnMBR}

Membrane permeability was evaluated at a sewage temperature of $9.6-12.6^{\circ} \mathrm{C}$ for fluxes of $7.5,12.0$ and $16.5 \mathrm{~L} \mathrm{~m}^{-2} \mathrm{~h}^{-1}$ when using a $10 \mathrm{~s}$ on/10s off gas sparging regime for fouling control (Figure 3). A steady-state filtration period was only evident at $7.5 \mathrm{~L} \mathrm{~m}^{-2} \mathrm{~h}^{-1}$ for the G-AnMBR, whereas at an equivalent flux for the F-AnMBR, a two-stage fouling curve seemingly developed in which a slow rise in TMP was followed by a faster rise in TMP initiating at around 140h (Figure 3).

\subsection{Impact of temperature on membrane permeability}

The impact of temperature on membrane permeability in G-AnMBR and F-AnMBR was evaluated through long term operation in two seasonal periods (Winter and Summer) (Figure 4) characterised by temperature ranges of $10-13^{\circ} \mathrm{C}$ and $21-23^{\circ} \mathrm{C}$ respectively (Table 4). Whilst absolute pressure was slightly higher in the G-AnMBR at $12.6 \pm 1.6^{\circ} \mathrm{C}$, similar fouling rates $(\mathrm{d} P / \mathrm{d} t)$ of 0.286 and $0.276 \mathrm{mbar}^{-1}$ were recorded at $12.6 \pm 1.6^{\circ} \mathrm{C}$ and $22.4 \pm 1.8^{\circ} \mathrm{C}$ respectively (Figure 4). When F-AnMBR was operated at $21.3 \pm 1.7^{\circ} \mathrm{C}$, analogous permeability behaviour to G-AnMBR was observed whereas at the lower temperature range, a significant increase in 
TMP was observed. A significant increase in MLSS and particulate COD was identified when FAnMBR was operated at the lower temperature range (Table 4). Critical flux $\left(J_{c}\right)$ analysis of the F-AnMBR matrix from each operating period was determined using bench scale filtration equipment under standard conditions, and identified that whilst $J_{c}$ was similar, fouling rate was considerably higher for the F-AnMBR matrix at $10.7 \pm 2.7^{\circ} \mathrm{C}$ (Figure 4 , inset). Interestingly, when upflow velocity in the F-UASB was reduced from 0.8 to $0.35 \mathrm{~m} \mathrm{~h}^{-1}$ at similar temperature $\left(10.7-12.7^{\circ} \mathrm{C}\right)$, statistically significant reduction in MLSS, particulate COD and SMP $(p<0.05$, Table 4) was observed by $31-36 \%$. The resultant permeability trend was ostensibly similar to the G-AnMBR at equivalent temperature (Figure 5).

\subsection{Alternative pseudo dead-end gas sparging strategy}

The application of pseudo dead-end gas sparging to both G-AnMBR and F-AnMBR was evaluated since this has recently been identified as a method to minimise specific gas demand in UASB configured AnMBR $[1,7,21]$. A 1 minute gas sparge was employed simultaneously within a period of relaxation, following a 10 minute pseudo dead-end filtration cycle (Figure 6). For both AnMBR, lower permeabilities were achieved using pseudo dead-end gas sparging than conventional gas sparging conditions (10s/10s off; continuous filtration), whilst the overall fouling rates (based on 200h data) were similar for F-AnMBR whether operated using standard or pseudo dead-end filtration conditions.

The impact of temperature on using pseudo dead-end gas sparging was subsequently investigated. During the low temperature period, fouling rates of 0.13 and $0.30 \mathrm{mbar} \mathrm{h}^{-1}$ were recorded for the G-AnMBR and F-AnMBR respectively using pseudo dead-end gas sparging regime (Figure 7a). However, when pseudo dead-end filtration conditions were applied during the higher temperature period, similar fouling rates were achieved with both AnMBRs (Figure 7a), and their permeabilities were comparable to those achieved for G-AnMBR using conventional gas sparging in both seasonal periods (Figure 7a, inset). Characterisation of the pseudo dead-end filtration cycles showed the cake fouling rate recorded for F-AnMBR during the low temperature period $\left(r_{f}, d P / d t 1.7 \mathrm{mbar} \mathrm{min}^{-1}\right)$ to be two times higher than when FAnMBR was operated at $22.8 \pm 3.1^{\circ} \mathrm{C}$, or for $\mathrm{G}$-AnMBR operated at a comparable temperature (Figure 7b). Characterisation of the foulant layer that developed during dead-end filtration 
evidenced that whilst SMP deposition was predominantly in the lower layer, resistance was primarily associated with the upper layer which comprised the richest organic fraction and was displaced through physically rinsing the membrane (Figure 8).

\section{Discussion}

This study has demonstrated that sustained membrane permeability can be achieved for both granular and flocculent inoculum in UASB configured AnMBR using pseudo dead-end gas sparging to minimise energy demand and approaching to energy neutral sewage treatment, provided solids flux onto the membrane can be controlled. The transition from UASB to AnMBR overcame the poor UASB treatment at low temperatures for both granular and flocculent systems, providing similar suspended-solids free permeate with consistently low $\mathrm{COD}_{\mathrm{t}}$ and $\mathrm{BOD}_{5}$ (Table 1). The membrane addition also increased the $500 \mathrm{kDa}$ to $1.2 \mu \mathrm{m}$ colloidal SMP fraction by an order of magnitude (Table 3). This size fraction has previously been linked to the higher fouling propensity in flocculated CSTR configured AnMBR [5] and was coincident with a reduction in critical flux in this study for both AnMBR (Figure 2). At a wastewater temperature of $21-22^{\circ} \mathrm{C}$, membrane permeability in the flocculent AnMBR was also comparable to that of the granular AnMBR, in which a slow rise in TMP was observed, analogous to that of 'stage one' fouling [22] (Figure 4). However, following a reduction in operating temperature to $10.7^{\circ} \mathrm{C}$, the onset of 'stage-two' fouling was observed in the FAnMBR [21] in which a rapid increase in fouling proceeded at around 50h operation (Figure 3, Figure 4). At this temperature, particulate COD and colloidal SMP ${ }_{\text {COD }}$ fractions (MW between 10-100 kDa) were significantly higher in the F-AnMBR membrane tank compared with that in G-AnMBR (Table 2, Table 3). We propose that the increase in particulate COD is due to the reduction in viscosity $\left(1.30\right.$ to $0.98 \mathrm{mPa} \mathrm{s}^{-1}$ at $\left.10^{\circ} \mathrm{C}\right)$, which decreased particle settling velocity $\left(v_{s}\right)$ by around $25 \%$ in the UASB thereby increasing the probability for smaller particles to breakthrough into the membrane tank [23]:

$v_{s}=\frac{g d^{2}\left(\rho_{s}-\rho_{f}\right)}{18 \mu}$

where $d$ is diameter, $\rho_{s}$ is the density of the solid, $\rho_{f}$ density of the fluid, $\mu$ is viscosity and $g$ is the gravitational constant. The increase in colloidal SMP ${ }_{\text {COD }}$ can be attributed to the breakage 
of this more concentrated particle fraction [21], which was corroborated by a reduction in the median particle size (Table 2), and is similar to observations of Martin et al. $[1,4]$ in which an increase in 10-100 kDa SMPCOD was associated to floc erosion arising from gas sparging. Confirmation was provided through reducing upflow velocity equivalent to the critical value identified by Lew et al. [24] to limit solids breakthrough $\left(V_{\text {up }} 0.35 \mathrm{~m} \mathrm{~h}^{-1}\right)$. This reduced particulate COD and SMP $P_{C O D}$ in F-AnMBR similar to concentrations present in the G-AnMBR (at an equivalent temperature) (Table 4), which subsequently permitted comparable permeability to G-AnMBR to be achieved (Figure 5). For granular AnMBR, comparable fouling transients were observed at 12.6 and $22.4^{\circ} \mathrm{C}$, despite maintaining an upflow velocity of $0.8 \mathrm{~m}$ $\mathrm{h}^{-1}$. We suggest the higher density and particle size $(0.5-3 \mathrm{~mm})$ of the granular biomass introduces substantive inertia, which improves energy dissipation and reduced mixing, thereby limiting solids breakthrough [25]. As granule disintegration may occur during long term operation, which may offset the advantage of granules [14], further long-term comparison between granular and flocculent inoculum biomass on membrane permeability would be beneficial.

Comparable permeabilities and fouling rates to G-AnMBR operated in a standard 10s/10s gas sparging mode, were determined for both F-AnMBR and G-AnMBR when operated in pseudo dead-end mode at $22^{\circ} \mathrm{C}$ (Figure 7a). With this method of gas sparging, energy demand reduced by more than $80 \%$ to $0.122 \mathrm{kWh} \mathrm{m}^{-3}$, which is sufficient to deliver energy neutral wastewater treatment compared with the average energy production of 0.34 $\mathrm{kWh} \mathrm{m}^{-3}$ for AnMBR treating settled municipal wastewater $[7,26]$. The lower layer of the cake formed during pseudo dead-end gas sparging was predominantly SMP which is consistent with observations of Metzger et al. [27] in an aerobic MBR treating synthetic wastewater. However, it was the upper layer that was primarily responsible for hydraulic resistance, and was shown to be physically reversible (Figure 8). McAdam et al. [21] identified the cake layer formed under dead-end conditions to be more reversible than when using continuous gas sparging, which was attributed to the increased heterogeneity of the cake. The authors used the critical mass concept proposed by Harmant and Aimar [28] in determining a critical solids flux after which compaction occurred, initiating irreversible fouling. At low temperature, lower 
permeability and a higher fouling rate was identified for F-AnMBR (Figure 7a), which is credited to the higher cake fouling rate $\left(r_{f}\right)$ determined during pseudo dead-end cycles (Figure 7b). Vera et al. [18] described cake reversibility to also be dependent upon its compressibility, which is determined by the composition of the matrix [7]. Specific cake resistances were similar $\left(\alpha, 10^{13}-10^{14} \mathrm{~m} \mathrm{~kg}^{-1}\right.$; Equation 9) for the G-AnMBR and F-AnMBR at high and low average temperatures. We therefore suggest it is the net solids flux onto the membrane rather than the character of the cake which increased $r_{f}$ in F-AnMBR at low temperatures. Consequently, through adaptation of shorter filtration cycles, comparable permeabilities to those attained with G-AnMBR should be achievable. This is supported by previous research on the adaptation of dead-end gas sparging into MBR in which sustainable fluxes can be achieved at fluxes above the critical flux, through optimisation of the filtration cycle $[7,21]$. Importantly, pseudo deadend filtration conditions can provide low energy sustained membrane operation in both FAnMBR and G-AnMBR provided solids flux onto the membrane is managed through controlling solids retention in the UASB, and specifying cycle length to avoid the onset of critical mass deposition.

\section{Conclusions}

This study demonstrated that whilst granular inoculum promotes greater stability in AnMBR, analogous membrane performance can be ascertained with flocculent through adoption of solids management strategies. This is of significance since the present sources of granular sludge are limited and potentially costly, which presents a risk to process resilience and its ultimate sustainability, whereas flocculent can be readily accessed from available anaerobic digestion facilities. Consequently, sustainable membrane operation can be achieved for both granular and flocculent UASB configured AnMBR, promoting to achieve energy neutral sewage treatment. The following conclusions can be drawn:

- Poor UASB performance was observed for both inoculum biomass at around $10^{\circ} \mathrm{C}$, which can be overcome by membrane integration, providing solids-free permeate with consistently low $\mathrm{COD}_{\mathrm{t}}$ and $\mathrm{BOD}_{5}$ of $34-39 \mathrm{mg} \mathrm{L}^{-1}$ and $10-13 \mathrm{mg} \mathrm{L}^{-1}$ respectively for both $\mathrm{G}-$ AnMBR and F-AnMBR.

- Membrane inclusion concentrated pCOD by 6-9 times and whilst an increase in colloidal 
SMP by about 2-4 times was also observed, which was associated to particle breakage through gas sparging.

- Whilst more consistent membrane permeability was ascertained for the granular inoculum, comparable permeability was achieved with flocculent biomass when operated at high temperatures $\left(22^{\circ} \mathrm{C}\right)$.

- The permeability reduction observed with F-AnMBR at a low temperature of $10^{\circ} \mathrm{C}$ was due to the reduction in particle settling velocity in the UASB which increased the particle load onto the membrane. Introducing solids management strategies such as optimising upflow velocity, and controlling sludge blanket height can resolve washout sufficient to similar membrane permeability to G-AnMBR, as evidenced in this study through a reduction in upflow velocity.

- Pseudo dead-end gas sparging was achievable in both granular and flocculent AnMBRs, providing equivalent permeability and fouling rates to conventional 10s/10s gas cycling, but using only one-fifth of the energy demand $\left(0.122 \mathrm{kWh} \mathrm{m}^{-3}\right)$; such a significant reduction in energy is necessary to achieve energy neutrality which remains a core ambition of the technology.

- An increased solids flux onto the membrane, increased cake fouling rate during the pseudo dead-end filtration cycle. To sustain permeability in response to an elevated solids concentration, filtration cycle length can be specified to constrain solids deposition below a critical value. Further research in applying feedback control based on permeability and TMP set-point for pseudo dead-end gas sparging and optimising the pseudo dead-end cycle length is warranted to evaluate the capacity for further improvement in flux and net energy demand.

\section{Acknowledgement}

The authors would like to thank our industrial sponsors Anglian Water, Severn Trent Water, Scottish Water and Thames Water for their financial and technical support. The authors also want to thank Suez (formerly GE Water \& Process Technologies, Canada) who provided the membrane for this work. 


\section{References}

[1] I. Martin Garcia, M. Mokosch, A. Soares, M. Pidou, B. Jefferson, Impact on reactor configuration on the performance of anaerobic MBRs: Treatment of settled sewage in temperate climates, Water Res. 47 (2013) 4853-4860.

[2] S. Chong, T.K. Sen, A. Kayaalp, H.M. Ang, The performance enhancements of upflow anaerobic sludge blanket (UASB) reactors for domestic sludge treatment - A State-of-the-art review, Water Res. 46 (2012) 3434-3470.

[3] A. Robles, M.V. Ruano, F. García-Usach, J. Ferrer, Sub-critical filtration conditions of commercial hollow-fibre membranes in a submerged anaerobic MBR (HF-SAnMBR) system: the effect of gas sparging intensity, Bioresour. Technol. 114 (2012) 247-254.

[4] I. Martin-Garcia, V. Monsalvo, M. Pidou, P. Le-Clech, S.J. Judd, E.J. McAdam, B. Jefferson, Impact of membrane configuration on fouling in anaerobic membrane bioreactors, J. Memb. Sci. 382 (2011) 41-49.

[5] E. van Voorthuizen, A. Zwijnenburg, W. van der Meer, H. Temmink, Biological black water treatment combined with membrane separation, Water Res. 42 (2008) 4334-4340.

[6] H. Ozgun, J.B. Gimenez, M. Evren, Y. Tao, H. Spanjers, J.B. van Lier, Impact of membrane addition for effluent extraction on the performance and sludge characteristics of upflow anaerobic sludge blanket reactors treating municipal wastewater, J. Memb. Sci. 479 (2015) 95-104.

[7] K.M. Wang, D. Cingolani, A.L. Eusebi, A. Soares, B. Jefferson, E.J. McAdam, Identification of gas sparging regimes for granular anaerobic membrane bioreactor to enable energy neutral municipal wastewater treatment, J. Memb. Sci. 555 (2018) 125-133.

[8] Y. Liu, J.H. Tay, State of the art of biogranulation technology for wastewater treatment, Biotechnol. Adv. 22 (2004) 533-563.

[9] Y. Liu, H.L. Xu, K.Y. Show, J.H. Tay, Anaerobic granulation technology for wastewater treatment, World J. Microbiol. Biotechnol. 18 (2002) 99-113.

[10] T. Sabry, Application of the UASB inoculated with flocculent and granular sludge in treating sewage at different hydraulic shock loads, Bioresour. Technol. 99 (2008) 4073-4077.

[11] S. Aiyuk, I. Forrez, D.K. Lieven, A. van Haandel, W. Verstraete, Anaerobic and complementary 
treatment of domestic sewage in regions with hot climates-A review, Bioresour. Technol. 97 (2006) 2225-2241.

[12] J.B. van Lier, F.P. van der Zee, C.T.M.J. Frijters, M.E. Ersahin, Celebrating 40 years anaerobic sludge bed reactors for industrial wastewater treatment, Rev. Environ. Sci. Bio/Technology. 14 (2015) 681-702.

[13] G. Lettinga, R. Roersma, P. Grin, Anaerobic treatment of raw domestic sewage at ambient temperatures using a granular bed UASB reactor, Biotechnol. Bioeng. 25 (1983) 1701-1723.

[14] S. Aiyuk, W. Verstraete, Sedimentological evolution in an UASB treating SYNTHES, a new representative synthetic sewage, at low loading rates, Bioresour. Technol. 93 (2004) 269278.

[15] J. Gouveia, F. Plaza, G. Garralon, F. Fdz-Polanco, M. Peña, A novel configuration for an anaerobic submerged membrane bioreactor (AnSMBR), Bioresour. Technol. 198 (2015) 510519.

[16] S.J. Judd, Principles and Applications of Membrane Bioreactors in Water and Wastewater Treatment, 2nd ed., Elsevier, London,UK, 2011.

[17] L. Vera, E. González, I. Ruigómez, J. Gómez, S. Delgado, Analysis of backwashing efficiency in dead-end hollow-fibre ultrafiltration of anaerobic suspensions, Environ. Sci. Pollut. Res. 22 (2015) 16600-16609.

[18] L. Vera, E. Gonzalez, O. Diaz, R. Sanchez, R. Bohorque, J. Rodriguez-Sevilla, Fouling analysis of a tertiary submerged membrane bioreactor operated in dead-end mode at high-fluxes, J. Memb. Sci. 493 (2015) 8-18.

[19] APHA, Standard Methods for the Examination of Water and Wastewater, 21st ed., American Public Health Association, Washington D.C, 2005.

[20] P. Le Clech, B. Jefferson, I.S. Chang, S.J. Judd, Critical flux determination by the flux-step method in a submerged membrane bioreactor, J. Memb. Sci. 227 (2003) 81-93.

[21] E.J. McAdam, E. Cartmell, S.J. Judd, Comparison of dead-end and continuous filtration conditions in a denitrification membrane bioreactor, J. Memb. Sci. 369 (2011) 167-173.

[22] A. Pollice, A. Brookes, B. Jefferson, S. Judd, Sub-critical flux fouling in membrane bioreactors A review of recent literature, Desalination. 174 (2005) 221-230. 
[23] G. Lettinga, S. Rebac, G. Zeeman, Challenge of psychrophilic anaerobic wastewater treatment, Trends Biotechnol. 19 (2001) 363-370.

[24] B. Lew, S. Tarre, M. Belavski, M. Green, UASB reactor for domestic wastewater treatment at low temperatures: A comparison between a classical UASB and hybrid UASB-filter reactor, Water Sci. Technol. 49 (2004) 295-301.

[25] A. Tsutsumi, W. Chen, Y.H. Kim, Classification and characterization of hydrodynamic and transport behaviors of three-phase reactors, Korean J. Chem. Eng. 16 (1999) 709-720.

[26] P.L. McCarty, J. Kim, J. Bae, Domestic wastewater treatment as a net energy producer - Can this be achieved?, Environ. Sci. Technol. 45 (2011) 7100-7106.

[27] U. Metzger, P. Le-Clech, R.M. Stuetz, F.H. Frimmel, V. Chen, Characterisation of polymeric fouling in membrane bioreactors and the effect of different filtration modes, J. Memb. Sci. 301 (2007) 180-189.

[28] P. Harmant, P. Aimar, Coagulation of colloids retained by porous wall, AIChE J. 42 (1996) $3523-3532$. 


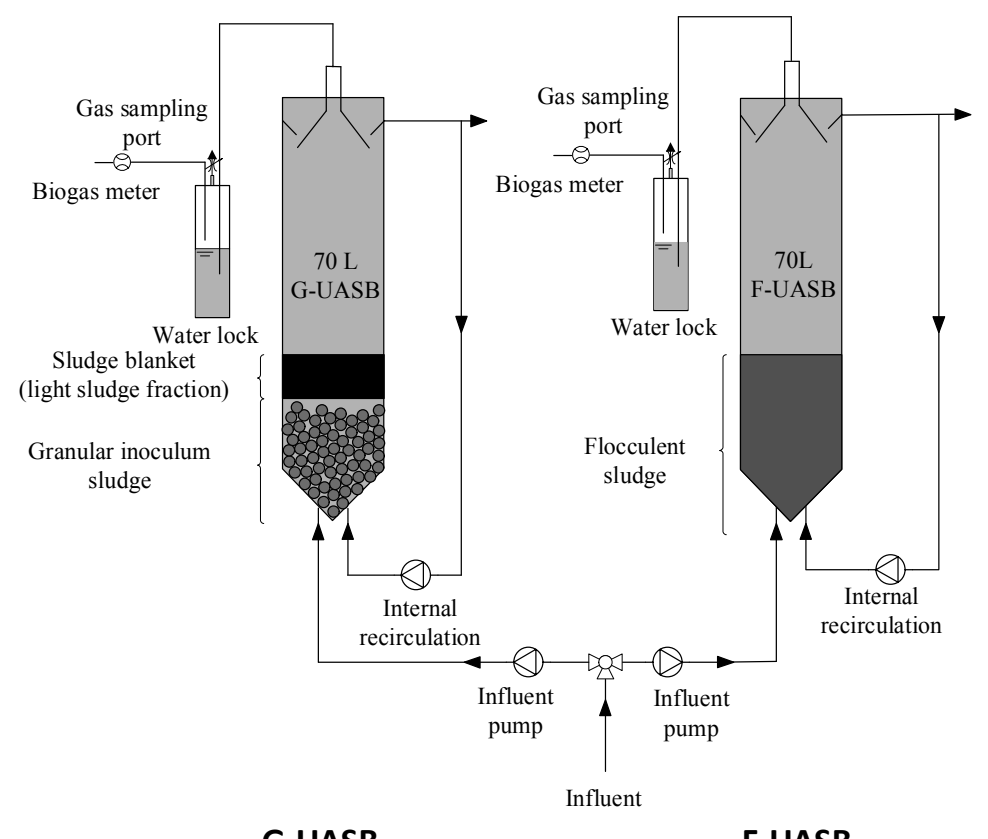

G-UASB

(a)
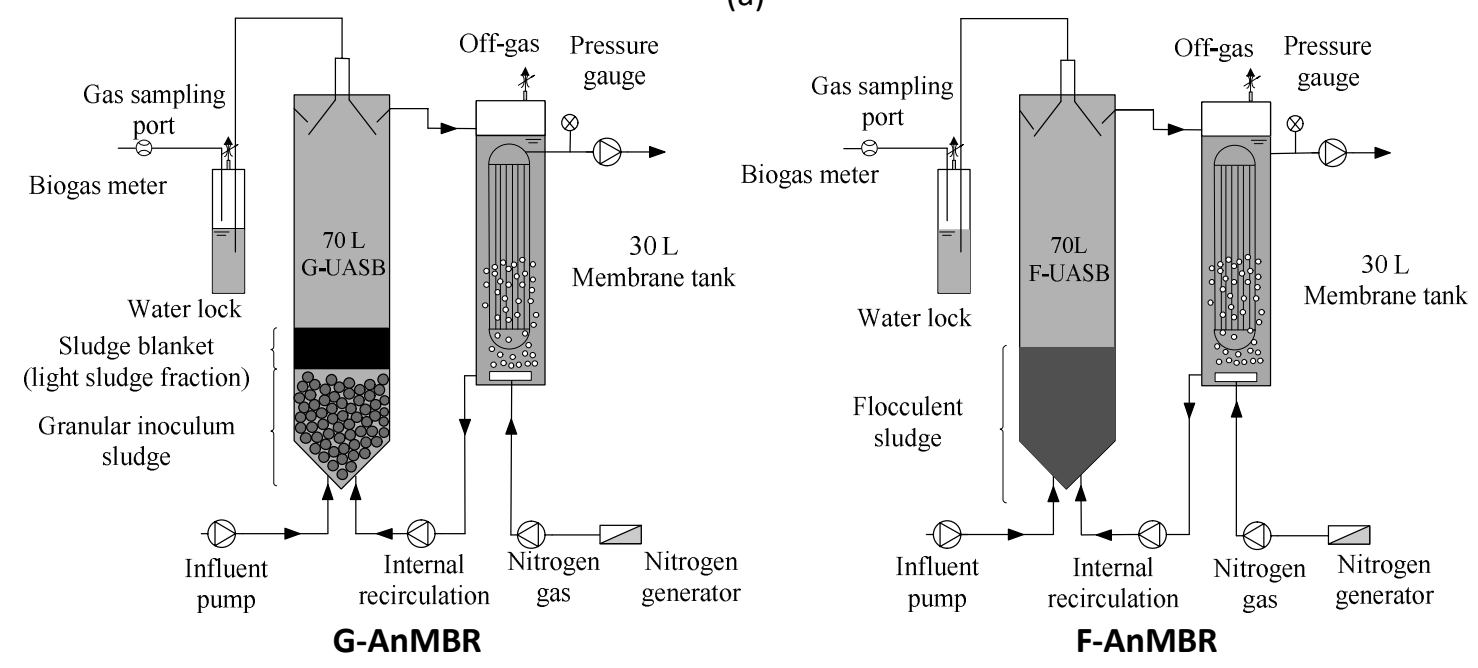

(b)

Figure 1. Experimental setup of (a) G-UASB and F-UASB, (b) Granular and flocculent UASB configured AnMBRs. 


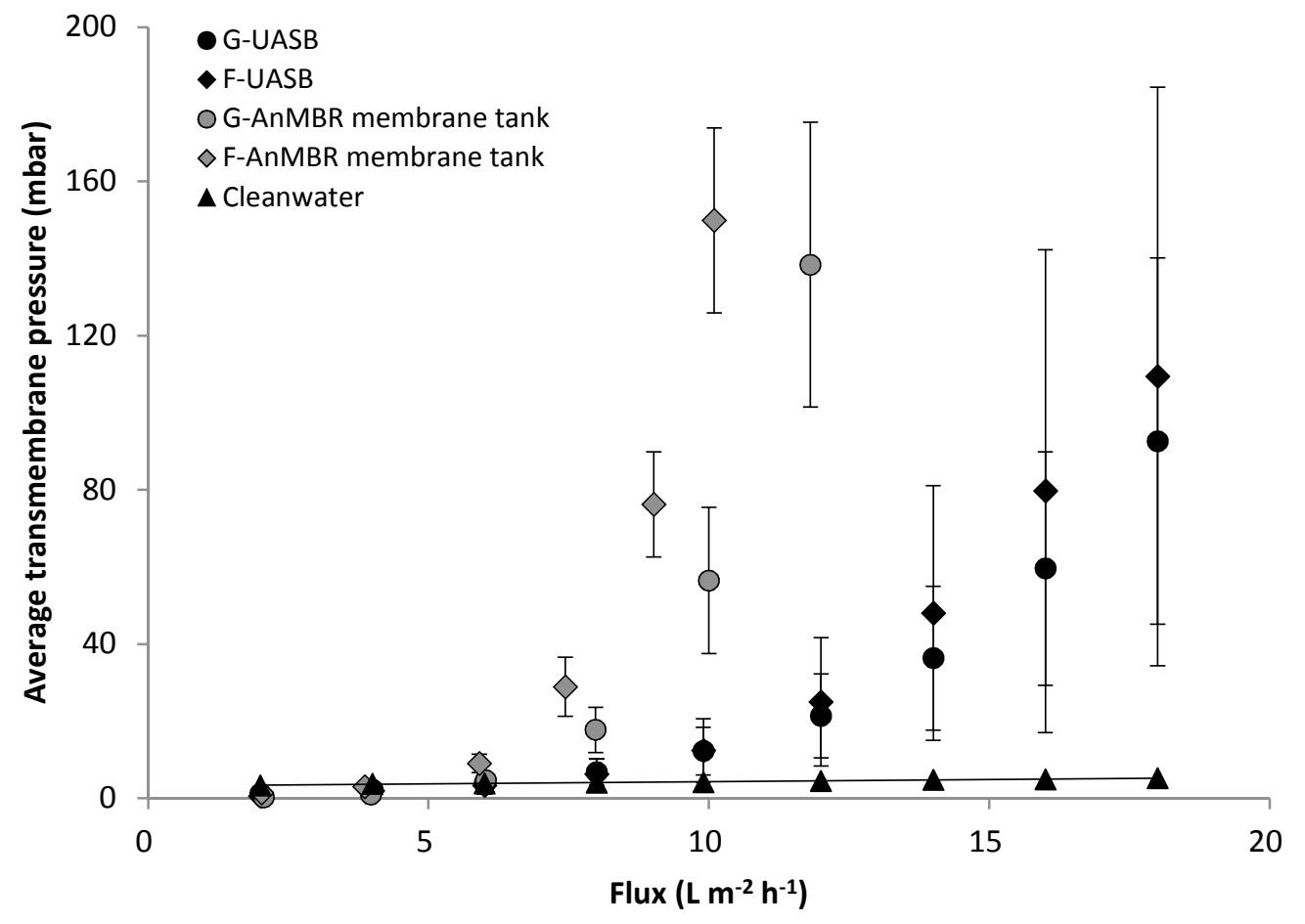

Figure 2. Bench scale critical flux tests $\left(2 \mathrm{~L} \mathrm{~m}^{-2} \mathrm{~h}^{-1}\right.$ per step; 15 mins step) undertaken on suspensions of G-UASB and F-UASB effluent when operated in UASB mode, from membrane tank in G-AnMBR and F-AnMBR when operated in UASB configured AnMBR mode. Samples collected when UASB and UASB configured AnMBR were operated at around $10^{\circ} \mathrm{C}$; UASB upflow velocity 0.8-0.9 $\mathrm{m} \mathrm{h}^{-1}$. 

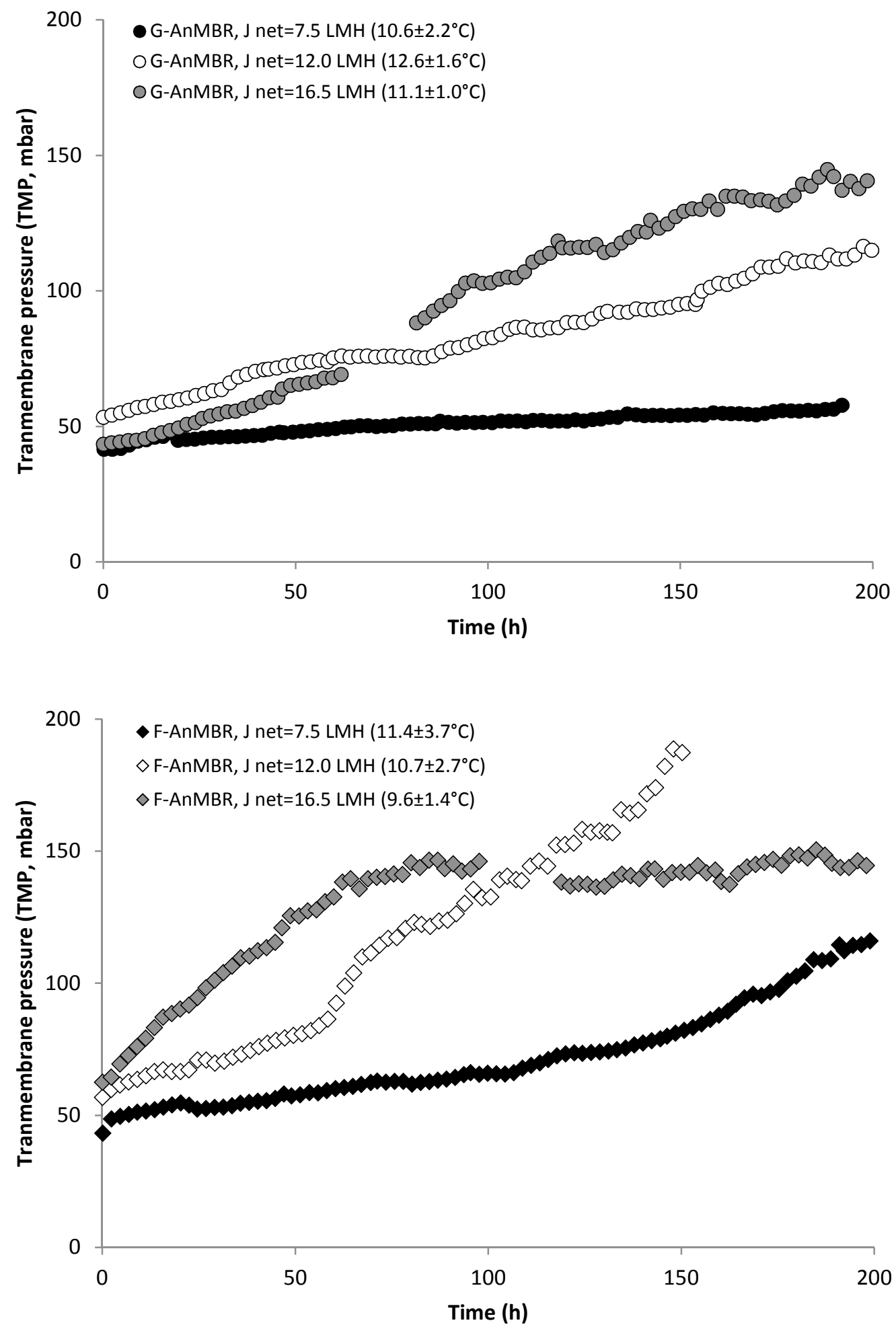

Figure 3. Membrane fouling transients determined at different fluxes for: (a) G-AnMBR; and (b) F-AnMBR when operated around $10^{\circ} \mathrm{C}$. Filtration/relaxation, $10 \mathrm{~min}$ on $/ 1 \mathrm{~min}$ off; cyclic gas sparging, $10 \mathrm{~s}$ on $/ 10 \mathrm{~s}$ off; $\mathrm{SGD}_{\mathrm{m}}=1.12 \mathrm{~m}^{3} \mathrm{~m}^{-2} \mathrm{~h}^{-1}\left(\mathrm{SGD}_{\text {mnet }}=0.56 \mathrm{~m}^{3} \mathrm{~m}^{-2} \mathrm{~h}^{-1}\right)$; UASB upflow velocity, 0.8-0.9 $\mathrm{m} \mathrm{h}^{-1}$. Flux normalised to $20^{\circ} \mathrm{C}$. 


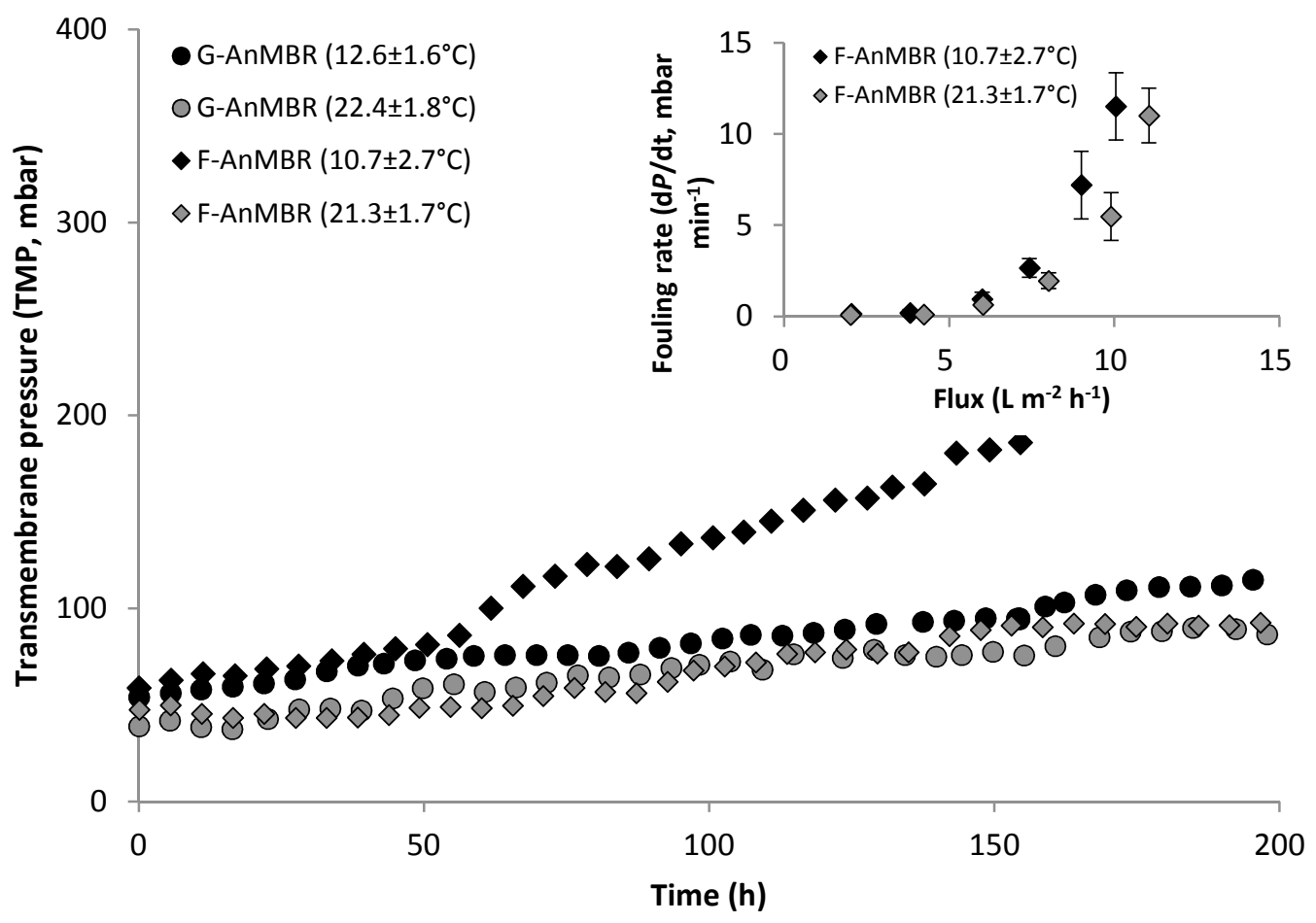

Figure 4. Membrane fouling transients determined at different fluxes for G-AnMBR and F-AnMBR when operated in winter (around $10^{\circ} \mathrm{C}$ ) and summer conditions (around $20^{\circ} \mathrm{C}$ ). Filtration/relaxation, $10 \mathrm{~min}$ on/1 min off; cyclic gas sparging, $10 \mathrm{~s}$ on/10 s off; $J_{20}$ net, $12 \mathrm{~L} \mathrm{~m}^{-2} \mathrm{~h}^{-1}$; UASB upflow velocity, 0.8-0.9 $\mathrm{m} \mathrm{h}^{-}$ 1. Inset: Bench scale critical flux analysis on F-AnMBR samples from the membrane tank at two temperatures. Analysis conducted at fixed ambient temperature $\left(20^{\circ} \mathrm{C}\right)$.

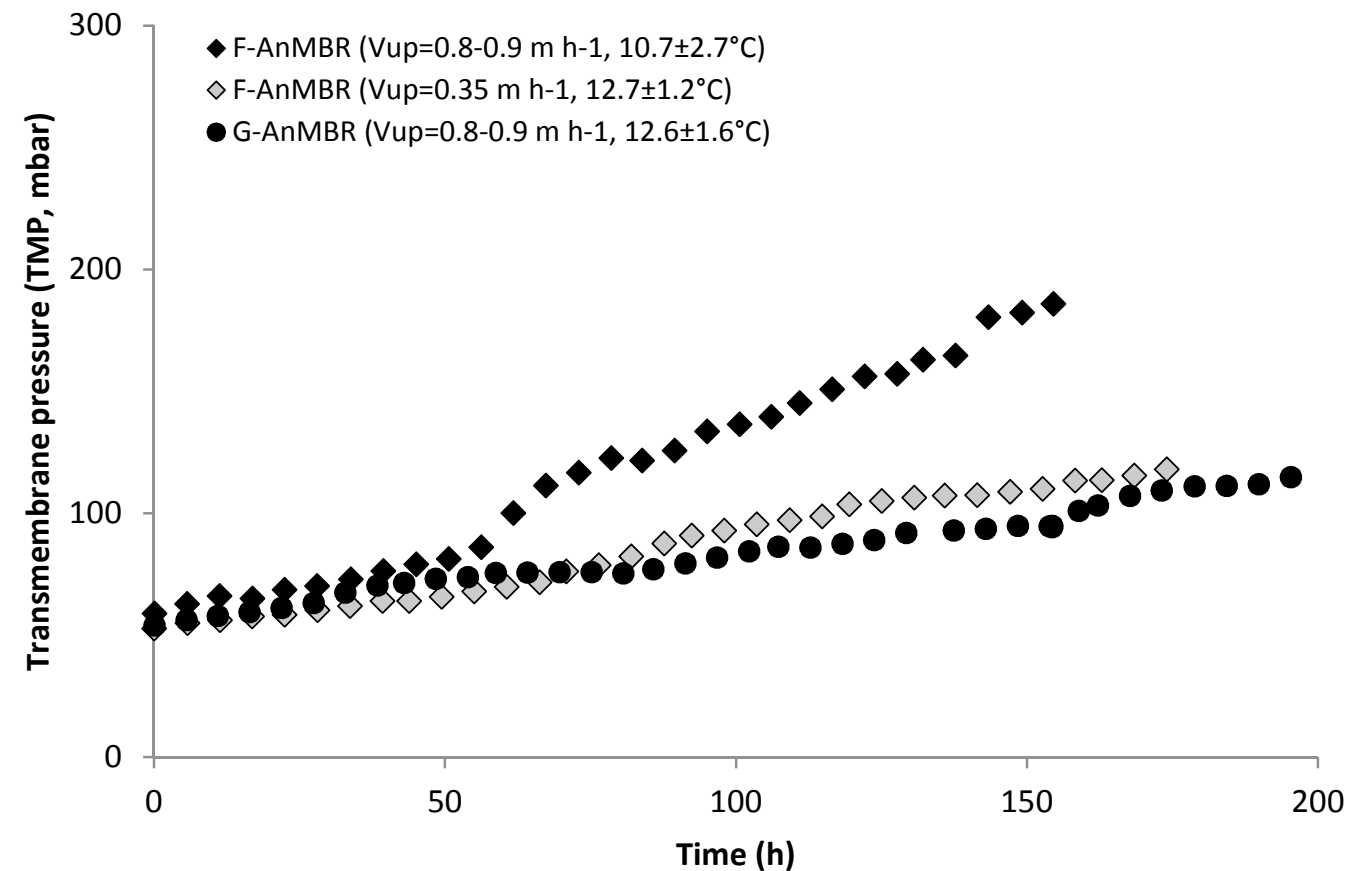

Figure 5. Impact of upflow velocity on membrane fouling. Filtration/relaxation, $10 \mathrm{~min}$ on/1 $\mathrm{min}$ off; cyclic gas sparging, $10 \mathrm{~s}$ on $/ 10 \mathrm{~s}$ off; $J_{20 \text { net, }} 12 \mathrm{~L} \mathrm{~m}^{-2} \mathrm{~h}^{-1}$. 


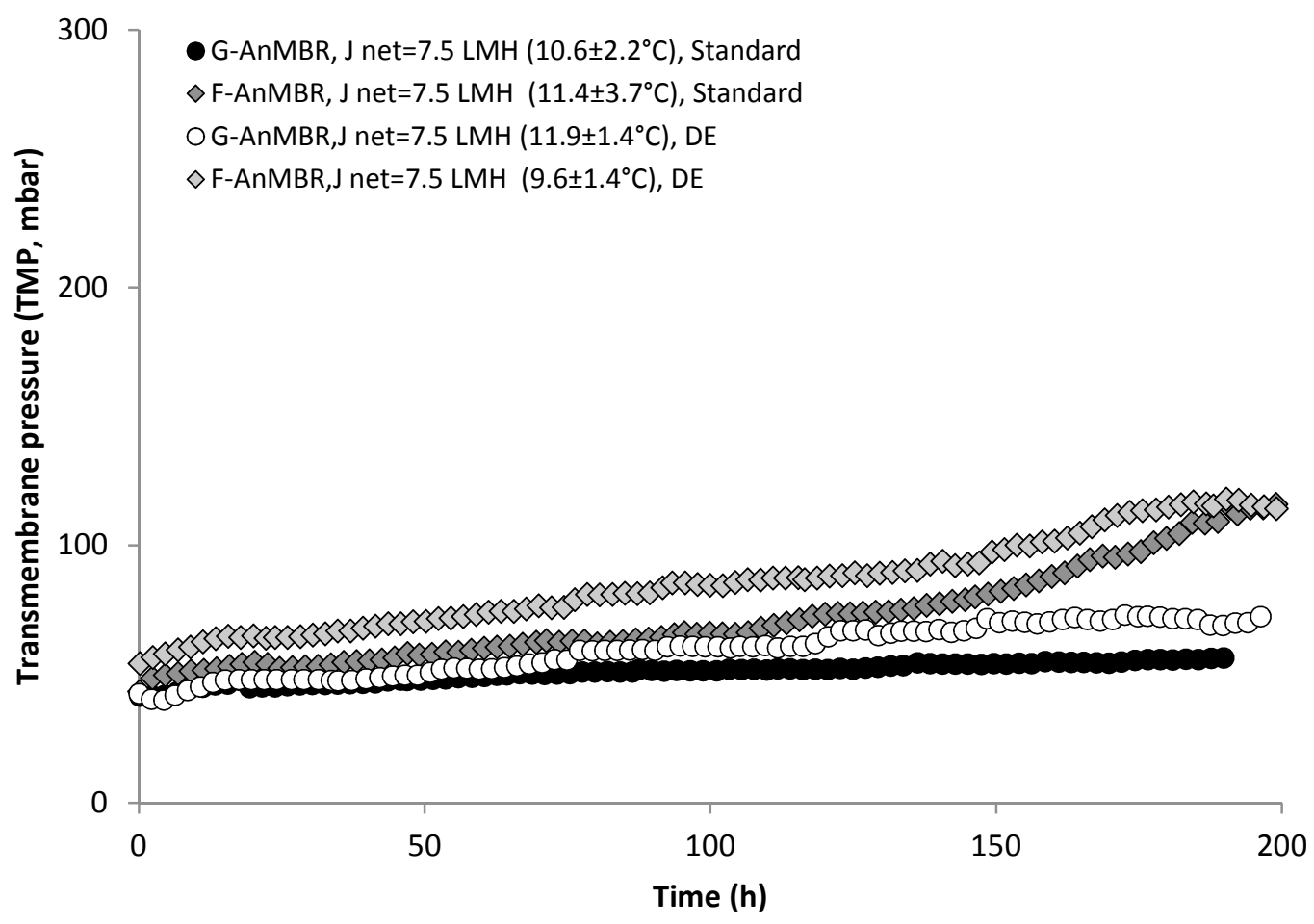

Figure 6. Comparison of pseudo dead-end gas sparging to standard gas sparging in G-AnMBR and F-AnMBR during the winter season. $J_{20 \text { net, }} 7.5 \mathrm{~L} \mathrm{~m}^{-2} \mathrm{~h}^{-1}$; UASB upflow velocity, 0.8-0.9 $\mathrm{m} \mathrm{h}^{-}$ 1. Standard: filtration/relaxation, $10 \mathrm{~min}$ on/1 min off; gas sparging, $10 \mathrm{~s}$ on/10 s off, $\mathrm{SGD}_{\mathrm{m}}=1.12$ $\mathrm{m}^{3} \mathrm{~m}^{-2} \mathrm{~h}^{-1}\left(\mathrm{SGD}_{\text {mnet }}=0.56 \mathrm{~m}^{3} \mathrm{~m}^{-2} \mathrm{~h}^{-1}\right)$. Dead-end (DE), filtration/relaxation, $10 \mathrm{~min}$ on/1 $\mathrm{min}$ off, gas sparging, $1 \mathrm{~min}$ on/10 min off; SGD $=1.12 \mathrm{~m}^{3} \mathrm{~m}^{-2} \mathrm{~h}^{-1}\left(\mathrm{SGD}_{\mathrm{mnet}}=0.102 \mathrm{~m}^{3} \mathrm{~m}^{-2} \mathrm{~h}^{-1}\right)$. Flux normalised to $20^{\circ} \mathrm{C}$. 


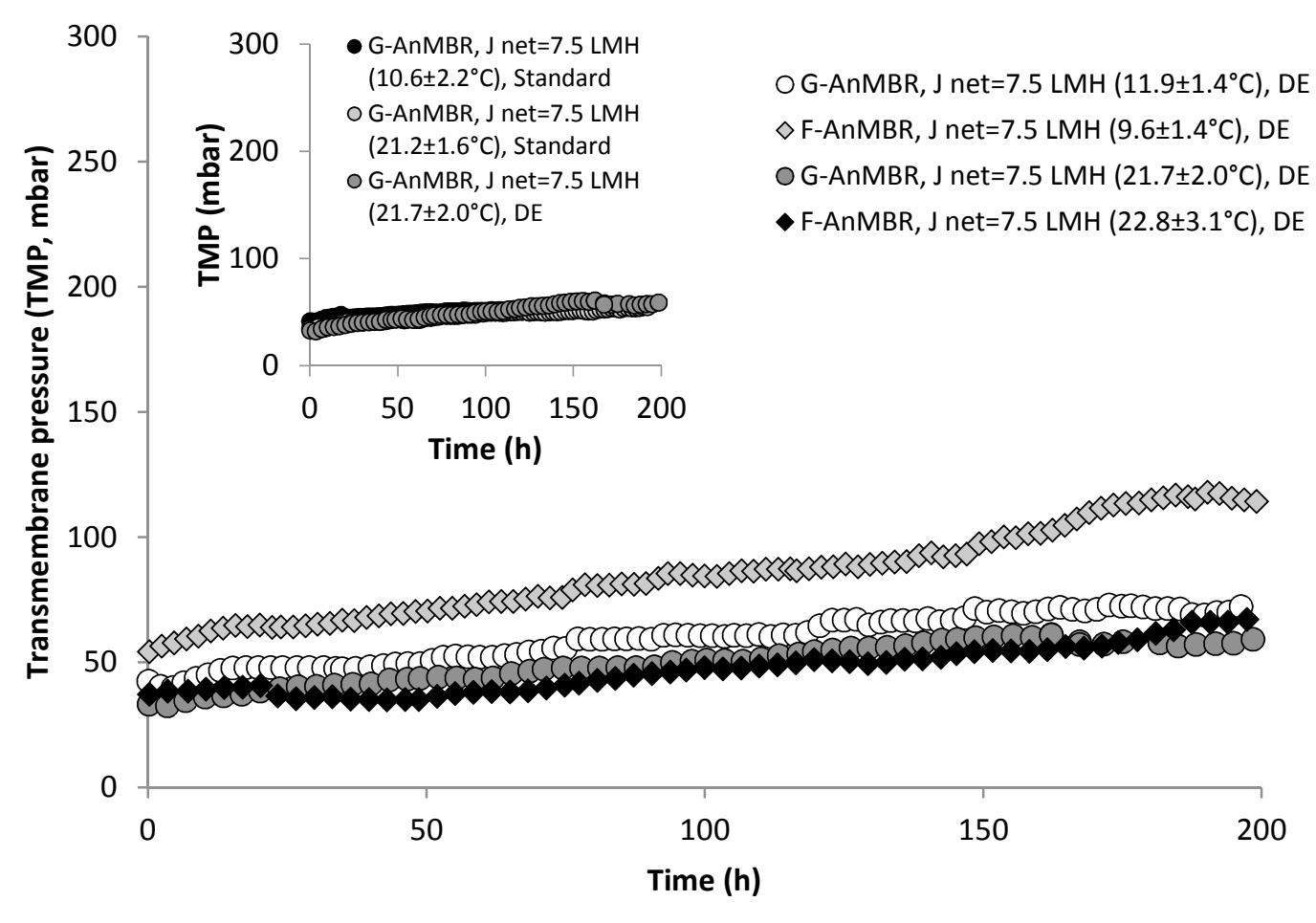

(a)

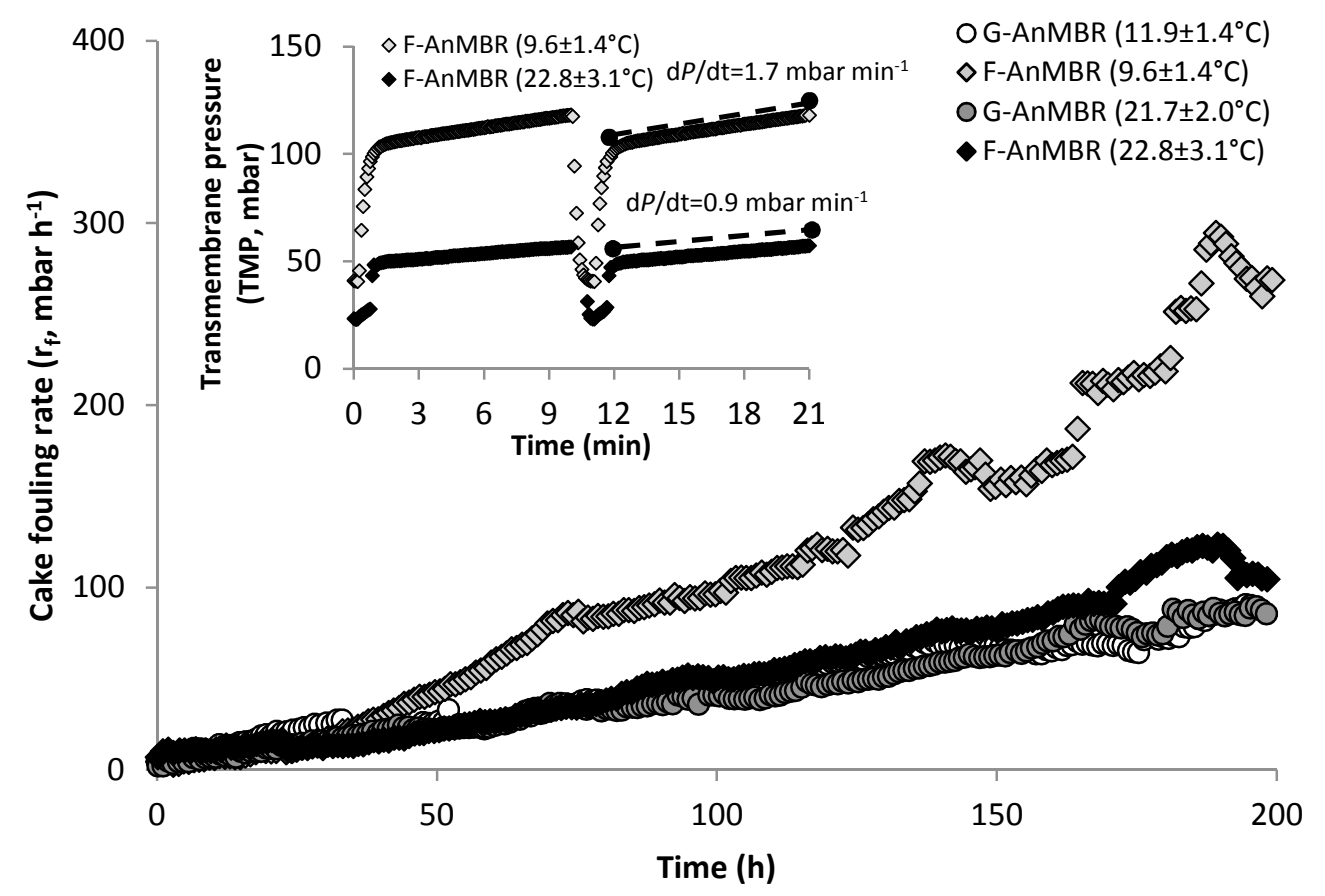

(b)

Figure 7. Impact of temperature on fouling in G-AnMBR and F-AnMBR at different temperatures when using pseudo dead-end gas sparging: (a) filtration/relaxation, $10 \mathrm{~min}$ on/1 min off, gas sparging, $1 \mathrm{~min}$ on/10 min off; $S \mathrm{SD}_{\mathrm{m}}=1.12 \mathrm{~m}^{3} \mathrm{~m}^{-2} \mathrm{~h}^{-1}\left(\mathrm{SGD}_{\text {mnet }}=0.102 \mathrm{~m}^{3} \mathrm{~m}^{-2} \mathrm{~h}^{-1}\right)$. Flux normalised to $20^{\circ} \mathrm{C}$. (b) Cake fouling rate $\left(r_{f}, d P / d t\right)$ determined for each filtration cycle. Inset: TMP after $100 \mathrm{~h}$. Flux normalised to $20^{\circ} \mathrm{C}$; UASB upflow velocity, 0.8-0.9 $\mathrm{m} \mathrm{h}^{-1}$. 

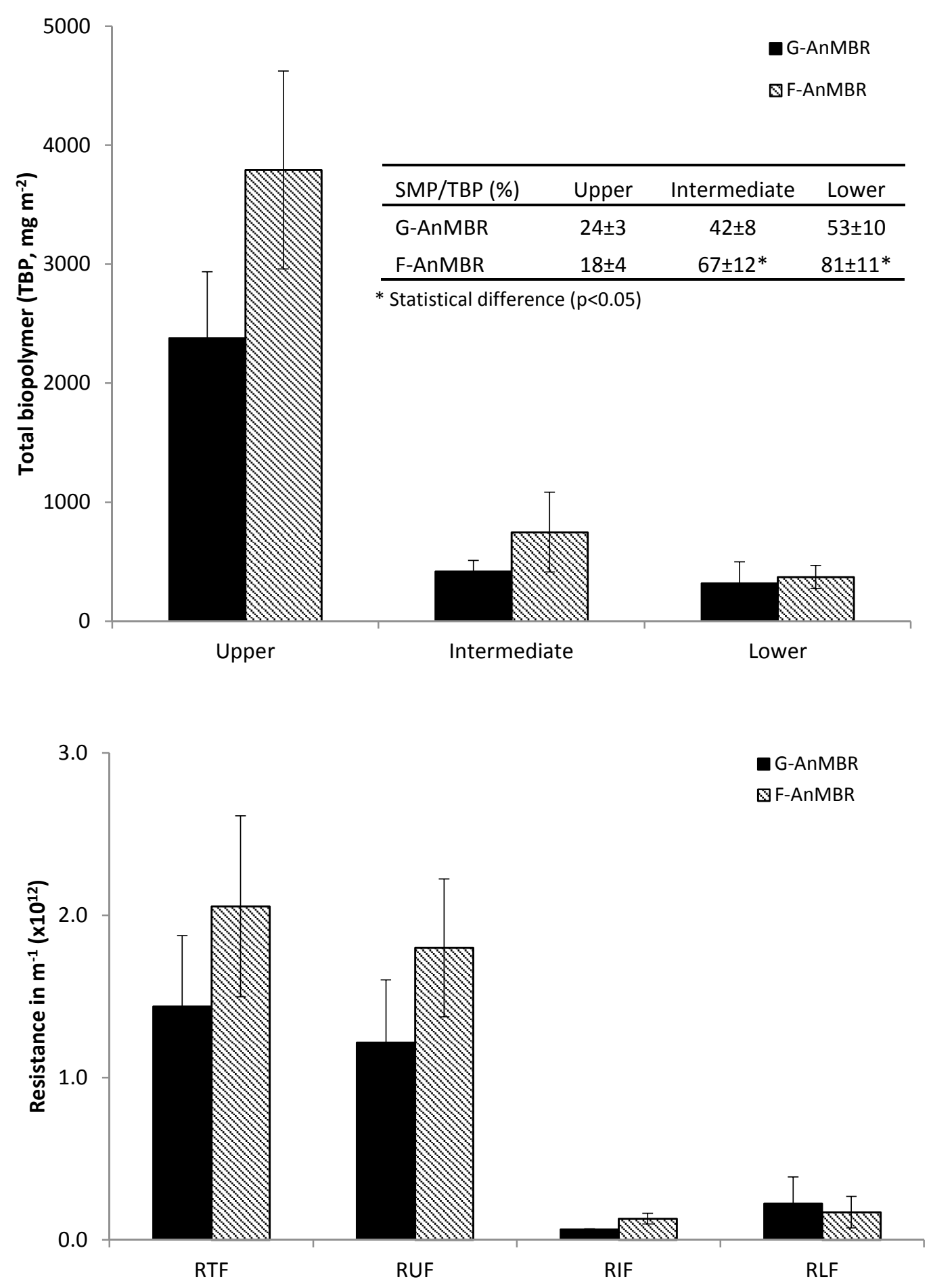

Figure 8. Total biopolymer (TBP) (protein + carbohydrates in $\mathrm{mg} \mathrm{m}^{-2}$ ) and hydraulic resistances determined for the cake formed in G-AnMBR and F-AnMBR after long term pseudo dead-end gas sparging (around $1500 \mathrm{~L} \mathrm{~m}^{-2}$ ). Filtration, $10 \mathrm{~min}$ on $/ 1 \mathrm{~min}$ off; $J_{20 \text { net }}=7.5 \mathrm{~L} \mathrm{~m}^{-2} \mathrm{~h}^{-1}$; gas sparging, $1 \mathrm{~min}$ on $/ 10 \mathrm{~min}$ off; $\mathrm{SGD}_{\mathrm{m}}=1.12 \mathrm{~m}^{3} \mathrm{~m}^{-2} \mathrm{~h}^{-1}\left(\mathrm{SGD}_{\text {mnet }}=0.102 \mathrm{~m}^{3} \mathrm{~m}^{-2} \mathrm{~h}^{-1}\right)$. UASB upflow velocity, 0.8-0.9 $\mathrm{m} \mathrm{h}^{-1}$. $R_{\mathrm{TF}}, R_{\mathrm{UF}}, \mathrm{R}_{\mathrm{IF}}$ and $\mathrm{R}_{\mathrm{LF}}$ represent total, upper, intermediate and lower cake resistances. 
Table 1. Impact of membrane addition on the treatment performance $\left(10-13^{\circ} \mathrm{C}\right)$.

\begin{tabular}{|c|c|c|c|c|c|c|}
\hline & & & G-UASB & F-UASB & G-AnMBR & F-AnMBR \\
\hline & Temperature & ${ }^{\circ} \mathrm{C}$ & $10.2 \pm 1.5$ & $10.2 \pm 1.5$ & $12.5 \pm 1.8$ & $13.1 \pm 1.8$ \\
\hline \multirow[t]{4}{*}{ TSS } & Influent & $\mathrm{mg} \mathrm{L}^{-1}$ & $113 \pm 23$ & $113 \pm 23$ & $105 \pm 9$ & $127 \pm 29 *$ \\
\hline & UASB effluent & $\mathrm{mg} \mathrm{L}^{-1}$ & $69 \pm 11$ & $75 \pm 9 *$ & $168 \pm 49$ & $325 \pm 72 *$ \\
\hline & Permeate & $\mathrm{mg} \mathrm{L}^{-1}$ & - & - & $<\mathrm{DL}$ & $<\mathrm{DL}$ \\
\hline & Removal & $\%$ & $42 \pm 13$ & $39 \pm 14 *$ & $>99$ & $>99$ \\
\hline \multirow[t]{4}{*}{$\mathrm{COD}_{\mathrm{t}}$} & Influent & $\mathrm{mg} \mathrm{L}^{-1}$ & $213 \pm 62$ & $213 \pm 62$ & $168 \pm 28$ & $208 \pm 83$ \\
\hline & UASB effluent & $\mathrm{mg} \mathrm{L}^{-1}$ & $129 \pm 19$ & $140 \pm 25^{*}$ & $304 \pm 84$ & $560 \pm 153^{*}$ \\
\hline & Permeate & $\mathrm{mg} \mathrm{L}^{-1}$ & - & - & $39 \pm 2$ & $34 \pm 3$ \\
\hline & Removal & $\%$ & $41 \pm 14$ & $36 \pm 16^{*}$ & $76 \pm 4$ & $89 \pm 4 *$ \\
\hline \multirow[t]{4}{*}{ SCOD } & Influent & $\mathrm{mg} \mathrm{L}^{-1}$ & $72 \pm 16$ & $72 \pm 16$ & $75 \pm 12$ & $88 \pm 24$ \\
\hline & UASB effluent & $\mathrm{mg} \mathrm{L}^{-1}$ & $64 \pm 13$ & $60 \pm 13$ & $97 \pm 16$ & $166 \pm 52^{*}$ \\
\hline & Permeate & $\mathrm{mg} \mathrm{L}^{-1}$ & - & - & $39 \pm 2$ & $34 \pm 3$ \\
\hline & Removal & $\%$ & $18 \pm 12$ & $24 \pm 14$ & $48 \pm 7$ & $55 \pm 5$ \\
\hline \multirow[t]{4}{*}{$\mathrm{BOD}_{5}$} & Influent & $\mathrm{mg} \mathrm{L}^{-1}$ & $107 \pm 22$ & $107 \pm 22$ & $88 \pm 9$ & $138 \pm 4 *$ \\
\hline & UASB effluent & $\mathrm{mg} \mathrm{L}^{-1}$ & $84 \pm 8$ & $88 \pm 10$ & $142 \pm 69$ & $249 \pm 61$ \\
\hline & Permeate & $\mathrm{mg} \mathrm{L}^{-1}$ & - & - & $10 \pm 5$ & $13 \pm 3$ \\
\hline & Removal & $\%$ & $26 \pm 17$ & $19 \pm 11$ & $89 \pm 5$ & $91 \pm 2$ \\
\hline
\end{tabular}

Table 2. Impact of membrane addition on bulk sludge characteristics.

\begin{tabular}{|c|c|c|c|c|c|}
\hline & & \multicolumn{2}{|c|}{ UASB effluent } & \multicolumn{2}{|c|}{ Membrane tank } \\
\hline & & G-UASB & F-UASB & G-AnMBR & F-AnMBR \\
\hline MLSS & $\mathrm{mg} \mathrm{L}^{-1}$ & $69 \pm 11$ & $75 \pm 9 *$ & $273 \pm 33^{\#}$ & $464 \pm 65^{*, \#}$ \\
\hline PSD & $\mu \mathrm{m}$ & & & & \\
\hline $\mathrm{d}_{10}$ & & $1.6 \pm 0.1$ & $3.4 \pm 0.4$ & $0.9 \pm 0.1^{\#}$ & $1.5 \pm 0.6^{\#}$ \\
\hline$d_{50}$ & & $85 \pm 7$ & $119 \pm 21 *$ & $18 \pm 7^{\#}$ & $68 \pm 6 *, \#$ \\
\hline $\mathrm{d}_{90}$ & & $564 \pm 201$ & $927 \pm 295$ & $81 \pm 5^{\#}$ & $345 \pm 65^{*, \#}$ \\
\hline Zeta potential & $\mathrm{mV}$ & $-13.3 \pm 1.4$ & $-15.3 \pm 3.0$ & $-12.4 \pm 1.5$ & $-16.2 \pm 1.3 *$ \\
\hline $\mathrm{pH}$ & & $7.8 \pm 0.1$ & $7.5 \pm 0.1^{*}$ & $8.1 \pm 0.1$ & $7.7 \pm 0.1^{*}$ \\
\hline $\mathrm{COD}_{\mathrm{t}}$ & & $129 \pm 19$ & $140 \pm 25^{*}$ & $533 \pm 13^{\#}$ & $971 \pm 216^{*, \#}$ \\
\hline PCOD & & $66 \pm 20$ & $80 \pm 17 *$ & $393 \pm 11^{\#}$ & $750 \pm 228 *, \#$ \\
\hline SMP COD & $\mathrm{mg} \mathrm{L}^{-1}$ & $64 \pm 13$ & $60 \pm 13$ & $140 \pm 22^{\#}$ & $222 \pm 12^{*, \#}$ \\
\hline SMP proteins & $\mathrm{mg} \mathrm{L}^{-1}$ & $13 \pm 1$ & $14 \pm 3$ & $54 \pm 8^{\#}$ & $88 \pm 22 *, \#$ \\
\hline SMP carbohydrates & $\mathrm{mg} \mathrm{L}^{-1}$ & $5 \pm 2$ & $6 \pm 0$ & $15 \pm 2^{\#}$ & $22 \pm 5^{*, \#}$ \\
\hline SMP P/C & & $2.8 \pm 0.7$ & $2.5 \pm 0.3$ & $3.7 \pm 0.5$ & $3.7 \pm 0.9$ \\
\hline $\begin{array}{l}\text { * Statistical differen } \\
\text { \# Statistical differen }\end{array}$ & $.05)$ & en G-UAS & d F-UASB, & $\mathrm{MBR}$ and & $\begin{array}{l}\mathrm{nMBR} \\
\mathrm{nMBR}\end{array}$ \\
\hline
\end{tabular}


Table 3. Colloidal SMP fractionation in UASB effluent and membrane tank bulk sludge $(n=3)$.

\begin{tabular}{lccccc}
\hline & \multicolumn{2}{c}{ UASB effluent } & & \multicolumn{2}{c}{ Membrane tank bulk } \\
\cline { 2 - 3 } \cline { 5 - 6 }$(\mathrm{kDa})$ & G-UASB & F-UASB & & G-AnMBR & F-AnMBR \\
\hline Total & $45.3 \pm 4.5$ & $56.3 \pm 3.8$ & & $135.7 \pm 7.1^{\#}$ & $174.3 \pm 2.5^{*}, \#$ \\
$\mathrm{X}>500$ & $8.3 \pm 5.5(18.4 \%)$ & $10.0 \pm 5.2(17.8 \%)$ & & $112.7 \pm 7.8(83.1 \%)^{\#}$ & $121.3 \pm 10.2(62.0 \%)^{\#}$ \\
$100<\mathrm{X}<500$ & $0.3 \pm 3.1(0.7 \%)$ & $2.0 \pm 4.0(3.6 \%)$ & & $0.3 \pm 5.5(0.3 \%)$ & $0.0 \pm 2.0(0.0 \%)$ \\
$10<\mathrm{X}<100$ & $4.7 \pm 5.5(10.3 \%)$ & $16.7 \pm 1.5(29.6 \%)^{*}$ & & $4.7 \pm 2.1(3.4 \%)$ & $23.0 \pm 9.5(13.2 \%)^{*}$ \\
$\mathrm{X}<10$ & $32.0 \pm 5.6(70.6 \%)$ & $27.7 \pm 1.5(49.1 \%)$ & & $30.0 \pm 1.0(22.1 \%)$ & $30.0 \pm 1.0(17.2 \%)$ \\
\hline All units are in mg COD L-1 & & & \\
$*$ Statistical difference $(\mathrm{p}<0.05)$ between G-UASB and F-UASB, G-AnMBR and F-AnMBR & \\
\# Statistical difference $(\mathrm{p}<0.05)$ between G-UASB and G-AnMBR, F-UASB and F-AnMBR & \\
\hline
\end{tabular}

Table 4. Impact of temperature and upflow velocity on G-AnMBR and F-AnMBR bulk sludge characteristics.

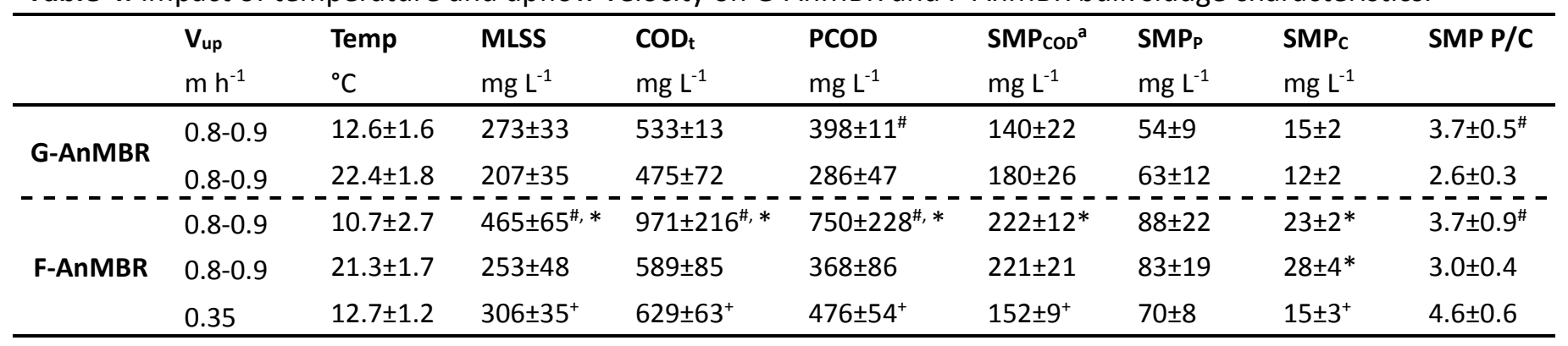

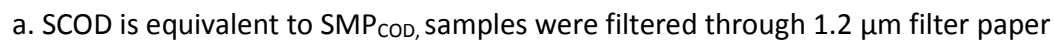

* Statistical difference $(p<0.05)$ between G-AnMBR and F-AnMBR at average temperature of 10.7-12.6 ${ }^{\circ} \mathrm{C}, \mathrm{G}-\mathrm{AnMBR}$ and F-AnMBR at average temperature of $21.3-22.4^{\circ} \mathrm{C}$.

\# Statistical difference $(\mathrm{p}<0.05)$ between $\mathrm{G}-\mathrm{AnMBR}$ at $12.6 \pm 1.6^{\circ} \mathrm{C}$ and $\mathrm{G}-\mathrm{AnMBR}$ at $22.4 \pm 1.8^{\circ} \mathrm{C}$, F-AnMBR at $10.7 \pm 2.7^{\circ} \mathrm{C}$ and F-AnMBR at $21.3 \pm 1.7^{\circ} \mathrm{C}$.

+ Statistical difference $(p<0.05)$ between F-AnMBR at $V_{\text {up }}$ of $0.8-0.9 \mathrm{~m} \mathrm{~h}^{-1}$ and $0.35 \mathrm{~m} \mathrm{~h}^{-1}$ under similar average temperature of $10.7-12.7^{\circ} \mathrm{C}$. 